\title{
CHSE PROTOCOL TRAINING IN TOURISM ATTRACTION FOR PASIR EURIH TOURISM VILLAGE MANAGERS, TAMAN SARI DISTRICT, BOGOR REGENCY-INDONESIA
}

\author{
Nafiah ARIYAN ${ }^{1 *}$, Marlinda IRWANTI² \\ ${ }^{1}$ Magister of Management Program of Sahid University, Indonesia \\ ${ }^{2}$ Master of Communication Program of Sahid University, Indonesia \\ *nafiah_ariyani@usahid.ac.id
}

\begin{abstract}
Tourism is the sector most affected by the COVID-19 pandemic. One of the efforts that can be made to stimulate tourism in Indonesia is applying hygiene, health, safety, and environmental sustainability (CHSE) protocols in every tourism destination. The successful implementation of CHSE is necessary to conduct socialization and training, especially for the managers of tourist destinations. This community service activity in socialization and CHSE training was carried out in the Pasir Eurih Tourism Village, Taman Sari District, Bogor Regency, West Java Province. The training method is lecture and discussion. The training participants are the Pasir Eurih Tourism Village managers, totaling 20 (twenty) people. Evaluation of the success of the activity was carried out pre-test and post-test. The post-test evaluation results showed an increase in the average knowledge of the managers of Pasir Eurih Tourism Village on the CHSE concept after training from the less to good category. The significance test results using SPSS software showed that the training had a significant effect on participants' knowledge of CHSE. Suggestions for improvement for further activities, training needs to be equipped with roleplaying and mentoring methods to improve participants' understanding of the CHSE protocol to practice properly organizing tourism activities during the Covid-19 pandemic.
\end{abstract}

Keywords: CHSE, Pasir Eurih Tourism Village, Covid-19 pandemic, tourism

\section{BACKGROUND}

The Covid-19 pandemic has had a significant impact on the tourism sector worldwide, and Indonesia is no exception. According to the international tourism organization (UNWTO), international tourist arrivals in various countries fell between $60 \%-80 \%$ in 2020 (Škare \& Rochon, 2021). The policy of social restrictions (physical distancing) and the prevention of entering or leaving the area (lockdown) carried out by various countries and regions domestically have been one of the triggers for the decline in tourism activities (Lin, Ling, Lin, \& Liang, 2021).

In Indonesia, the tourism sector is essential for the economy in line with its development and contribution to foreign exchange earnings, regional income, regional growth, and the absorption of investment and labor and business development spread across various regions (UI, 2019). However, since it was announced that it was affected by Covid-19 in March 2020, international tourist arrivals to Indonesia began to decline drastically and local tourism activities (Atmojo \& Fridayani, 2021). As a result, total foreign tourist visits in January-May 2020 decreased by 53.36 percent from the previous year, 6.3 million (Betty \& Kafabih, 2021).

To encourage the revival of Indonesian tourism, the government has set guidelines for CHSE-Cleanliness, Health, Safety, and Environment in tourist attractions through the Ministry of Tourism and Creative Economic. CHSE is a service handling procedure directed at prevention and control to prevent new Covid-19 epicenters or clusters (Kemenkraf, 2020). In addition, the CHSE protocol has adopted regulations issued by world organizations such as UNWTO.

The CHSE Guidelines were prepared based on the Decree of the Minister of Health No. HK.01.07/ Menkes/382/2020 concerning health protocols for the community in public places and facilities in the context of preventing and controlling Corona-19. CHSE in tourist attractions contains guidelines for entrepreneurs and managers, local tour guides, and employees to adapt to new habits (new norm). This CHSE guideline has complete clauses covering protocols for preparing tourist facilities, welcoming and serving visitors, to actions taken by managers/employees/tour guides in the event of a Covid-19 case at a tourist attraction.

As a new protocol, the implementation of CHSE has challenges that are not easy(Lumanauw, 2020). The successful implementation of CHSE in tourist attractions requires high support and discipline from the community, tourists, and tourist destination managers. For this reason, intensive socialization is needed so that the movement for the application of CHSE can be carried out simultaneously in all country regions. If the implementation of CHSE is successful, then people will not hesitate to travel so that Indonesian tourism will bounce back.

One of the tourist destinations affected by the COVID-19 pandemic is the Pasir Eurih Tourism Village in Taman Sari District, Bogor Regency. Before the pandemic, this tourist village showed good development marked by increasing tourists and increasingly diverse tourist attractions. The tourist village of Pasir Eurih by the Bogor Regency Government is declared a creative tourism village because it can integrate community entrepreneurial activities into tourist attractions. However, at this time, the manager has to stop its operations because it is feared that it will trigger the emergence of new clusters of Covid-19.

As a form of contribution from Sahid Jakarta University to the problems faced by Pasir Eurih Tourism Village, this community service activity was carried out in the form of socialization and training about CHSE in tourist attractions to the managers of Pasir Eurih Tourism Village. This activity hopes that the Pasir Eurih Tourism Village 
will be ready to operate again and serve tourists during the pandemic period based on the CHSE protocol correctly.

\section{OVERVIEW OFEURIHSANDTOURISM VILLAGE}

Pasir Eurih Tourism Village is located in Tamansari District, Bogor Regency. The location of the Pasir Eurih Tourism Village area is $6 \mathrm{~km}$ from the center of Bogor. Geographically, Pasir Eurih Tourism Village is located at an altitude of 500 - 700 meters above sea level, with a topography consisting of $70 \%$ flat land and 30\% hilly land. The Pasir Eurih Tourism Village area is 285,394 Ha, composed of 4 hamlets, 57 RT, and 14 RW. The total population is 11,913 people (3,823 families).

Pasir Eurih Tourism Village is included in the KSP (Tamansari Tourism Strategy Area) and the Pongkor Geopark area. This tourist village has been managed well, as shown by the management structure formed complete formation. Pasir Eurih Village has a variety of rural tourism attractions, including nature tourism, cultural tourism, craft tourism, culinary tourism, and artificial tourism.

The management has developed various tourist attractions based on local wisdom into tour packages, in the form of 1) learning to plant rice, plowing fields, farming, and vegetables; 2) tracking around the village and seeing shoe/sandal craftsmen, accessories; 3) tracking to sites in the village of Pasir Eurih, and listening to the guide's explanation of the history of the village; (3) visit and learn from roofing craftsmen and tourism awareness groups to make batik and make ornaments from wood; (4) learn with local culinary craftsmen; (5) learning about "overtime pay" and tourist attractions; (6) participating in traditional activities: annual seren, rebo wekasan, and munday; (7) playing in the pond/balong and catching fish.

The tour packages are offered to both individual and group tourists and are in daily tour packages and overnight tour packages. This tourist village has also been equipped with homestays prepared by residents. The condition of the homestay is quite good in terms of completeness and cleanliness. This tourist village is open every day.

Tourists who visit the Pasir Eurih Tourism Village are not only local tourists but also foreign tourists. Therefore, the number of tourists is quite large and has increased during 2017-2020, as presented in Figure 1. However, since the Pandemic-Covid 19, the number of tourist visits has decreased drastically. Almost no tourist activities are carried out.

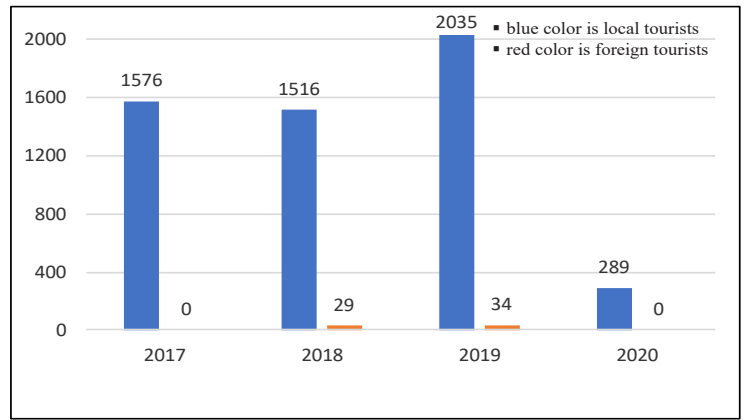

Source: Pasir Eurih Tourism illage, 2021

\section{FORMULATION OF THE PROBLEM}

Based on the conditions faced by Pasir Eurih Tourism Village, this community service activity is directed to answer the following problems:

1) How well do the managers of Pasir Eurih Tourism Village know about CHSE?

2) Are there differences in the knowledge of the Pasir Eurih Tourism Village managers about CHSE before and after the training?

\section{IMPLEMENTATION METHOD}

This community service activity is carried out in training by applying the lecture method (counseling) and discussion. The training participants are the managers and guides of the Pasir Eurih Tourism Village as many as 20 (twenty) people. The training was held for two days, every 4 hours. The training was held at the Pasir Eurih tourist village office.

Pre-test and post-test were conducted to evaluate the activities; the test is carried out by giving questions to participants with answers that have been provided in the form of multiple choice. The test questions consist of questions about a) general CHSE knowledge; b) knowledge that the manager, c must know) about knowledge of tourism management, d) about the flow of tourism services, e) about knowledge that tour guides, e must know) understanding of visitors and e) knowledge that employees must know.

The correct answer is given a score of 1 , while the wrong answer is given 0 . The final score is calculated using the following scale: $0-0.29$ : very poor; $0.3-0.49$ : less; 0.5-0.79: good; 0.8-1: very good, which describes the level of participants' understanding of CHSE. The mean value of the pre-test and post-test was then analyzed for significance. The training is said to be successful if the results of the post-test scores are significantly different from the pre-test scores.

\section{RESULTS AND DISCUSSION Pre-test Pelaksanaan}

The pre-test is a test that is carried out before training. At the pre-test stage, participants were given 20 questions. Then, the partners are asked to answer the questions by choosing the answers provided. The pre-test values are presented in Table 2.

\section{Implementation of Training}

The training was conducted using lectures, and the community service team carried out questionand-answer methods. The materials of exercise are all CHSE guidelines in tourist attractions, as presented in Table 1. The content of training are grouped into five groups, namely: 1) guides for managers and facilities that must be provided, 2) guides for visitors, 3 ) guides for tourists, 4) guide for tour guides, and 5) guide for employees. 
Table 1. CHSE Training Materials for Pasir Eurih Tourism Village

\begin{tabular}{ccl}
\hline No. & Guide Type & \multicolumn{1}{c}{ Content } \\
\hline 1 & General guide & Management/Governance \\
2 & Specific guide & Entrance \\
& & Counter, \\
& & Organizing tourism activities \\
& Facilities and public areas \\
& Exit \\
& Office \\
& Employee Room \\
\hline
\end{tabular}

\section{Implementation of Post-test}

After the training was completed, a post-test was carried out. The post-test was to determine whether there was a change in the CHSE after train compared to before. The post-test scores are presented in Table 2 .

From Table 2, it is known that the cumulative mean value of the pre-test is 0.38 , which is included in the less category. The lowest score in the pre-test was 0.35 , namely knowledge of the procedures for organizing tourism during the Covid-19 pandemic and expertise of employee procedures during the Covid-19 pandemic. While the highest pre-test score of 0.45 is about knowledge of CHSE in general. The pre-test results indicate that prior to the training, the trainees did not know or understand CHSE in tourist attractions.

In the post-test, the cumulative average value of 0.64 is included in the good category. The highest score in the post-test was knowledge about CHSE in general, which was 0.70 . At the same time, the lowest score is on learning about the procedures for organizing tourism during the Covid-19 pandemic, which is 0.58 . Thus, the post-test results showed an increase in participants' understanding of CHSE after the training. However, the increase in the value of participants' knowledge about CHSE has not reached the excellent category, which is, of course, very much needed to ensure that tourism activities during the pandemic are safe from exposure to the covid-19 virus.
The pre-test and post-test scores were then tested to determine whether there was a significant difference in participants' understanding of CHSE before and after the training. Using the paired-simple test and $95 \%$ confidence level $(\alpha=0.05)$, which was assisted by SPSS software, a sig value of 0.000 was found (Table 3 ). This finding shows the difference in scores before and after training is significant. Thus, it can be concluded that the exercise carried out affects participants' understanding of CHSE.

Table 3. Significance Test Results of the Effect of Training on Understanding of CHSE

Pairelil Samples Test

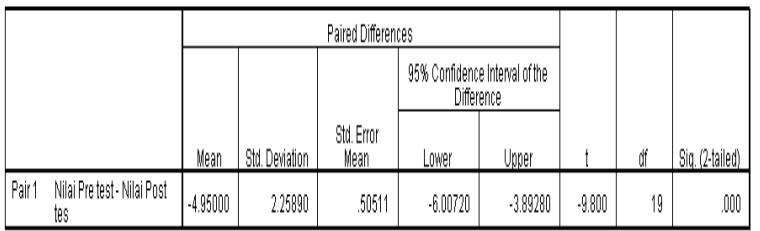

6. CONCLUSION and RECOMMENDATION

Training on the CHSE protocol for tourist attractions for the Wsata Pasir Eurih Village Manager, Taman Sari District, Bogor Regency, is suitable for managers to deal with the covid-19 pandemic. These results can be seen from the high interest of the participants, where the participants were fully present during the training. In addition, it can be seen from the pre-test and post-test scores that increased from the less category to the excellent category after the training. The significance test shows that the difference between the pre-test and post-test scores is significant. These findings indicate that this activity increases the understanding of the Pasir Eurih Tourism Village Manager about CHSE.

Forward, the training method needs to be equipped with role playing and mentoring to provide experience and monitoring. Moreover, given a large amount of CHSE material, the training requires a longer time to understand the training material better. However, with this approach, the manager's understanding will increase again. Therefore, it is hoped that tourism activities in Pasir Eurih Village can be held with the proper CHSE procedures to prevent COVID-19 cases.

Table 2. Pre-test and Post-test scores for CHSE Training

\begin{tabular}{|c|c|c|c|c|c|}
\hline Question & Content & $\begin{array}{l}\text { Pre-test Average } \\
\text { Score }\end{array}$ & Category & $\begin{array}{c}\text { Post-test } \\
\text { Average Score }\end{array}$ & Category \\
\hline $1-3$ & Knowledge of CHSE in general & 0,45 & less & 0,67 & Good \\
\hline $4-7$ & $\begin{array}{l}\text { Knowledge of tourism management procedures during } \\
\text { the Covid-19 pandemic }\end{array}$ & 0,38 & less & & good \\
\hline $8-11$ & $\begin{array}{l}\text { Knowledge of the procedures for organizing tours } \\
\text { during the Covid- } 19 \text { pandemic }\end{array}$ & 0,35 & less & 0,61 & good \\
\hline $12-14$ & $\begin{array}{l}\text { Knowledge of the flow of tourism services during the } \\
\text { Covid-19 pandemic }\end{array}$ & & less & & good \\
\hline $15-17$ & $\begin{array}{l}\text { Knowledge of tour guide procedures during the } \\
\text { Covid-19 pandemic }\end{array}$ & 0,4 & less & 0,58 & good \\
\hline 18-19 & $\begin{array}{l}\text { Understanding of visitor service procedures during the } \\
\text { Covid-19 pandemic }\end{array}$ & 0,38 & less & & good \\
\hline \multirow[t]{2}{*}{20} & $\begin{array}{l}\text { Knowledge of employee procedures during the } \\
\text { Covid-19 pandemic }\end{array}$ & 0,37 & less & 0,65 & good \\
\hline & Average score & 0,38 & less & 0,64 & Good \\
\hline
\end{tabular}

Category scale: :0-0.29: very poor; 0.3-0.49: less; 0.5-0.79: good; 0.8-1: very good

Source: Primary data from Pasir Eurih Village, processed 


\section{ACKNOWLEDGEMENT}

This community service activity is supported by the Research and Community Service Institute of Sahid University and funded by Sahid University's internal budget.

\section{REFERENCES}

Atmojo, M., \& Fridayani, H. (2021). An Assessment of Covid-19 Pandemic Impact on Indonesian Tourism Sector. Journal of Governance and Public Policy, 8(1-9). Retrieved from https://journal.umy.ac.id/ index.php/GPP/article/view/9792/6095

Betty, U., \& Kafabih, A. (2021). Sektor Pariwisata Indonesia Di Tengah Pandemi Covid 19. JDEP (Jurnal Dinamika Ekonomi Pembangunan), 4(1), 383-389. Retrieved from http://jdep.upnjatim.ac.id/ index.php/jdep/article/view/121

Kemenkraf. (2020). Rencana Strategis 2020-2024. Retrieved from https://www.kemenparekraf. go.id/asset_admin/assets/uploads/media/ $\mathrm{pdf} / \mathrm{media} 1598887965_{\text {_Rencana }}$ strategis_2020-2024.pdf
Lin, H. H., Ling, Y., Lin, J. C., \& Liang, Z. F. (2021). Research on the development of religious tourism and the sustainable development of rural environment and health. International Journal of Environmental Research and Public Health, 18(5), 1-20. https://doi.org/10.3390/ijerph18052731

Lumanauw, N. (2020). Edukasi dan Implementasi Protokol Clean Healthy Safety Environment Melalui We Love Bali Kemenparekraf Pada Program 10 SanurNusa Penida-Lembongan. Journal Hospitality Management, 11(1), 71-81. Retrieved from https:// jihm.stpbipress.id/index.php/JIHM/article/view/179

Škare, M., \& Rochon, M. (2021). Impact of COVID-19 on the travel and tourism industry. Technological Forecasting and Social Change, 163(November 2020). https://doi.org/10.1016/j. techfore.2020.120469

UI, L. P. E. dan M. F. (2019). Kajian Dampak Sektor Pariwisata Terhadap Perekonomian Indonesia. Retrieved from www.kemenparekraf.go.id > uploads $>$ media > pdf $\% 0 \mathrm{~A}$ 